DOI: http://dx.doi.org/10.12775/szhf.2014.019

\title{
Rola mass mediów w kulturze społeczeństwa jednowymiarowego Herberta Marcusego
}

\begin{abstract}
Filozof nie jest lekarzem; jego zadaniem nie jest leczenie jednostek, ale zrozumienie świata, w którym one żyja - zrozumienie go przez opis tego, co on uczynit człowiekowi i co może mu uczynić.

Herbert Marcuse
\end{abstract}

Rewolucja informacyjna, którą zwiastuje połączenie komputera z szybko rozwijającą się telekomunikacyjną siecią Internetu, nie tylko zmieniła dotychczasowe wyobrażenia o przestrzeni i czasie, ale także wpłynęła na zmiany w społeczeństwie jako takim. Ludzie otrzymali możliwość natychmiastowego komunikowania się i obcowania z przyjaciółmi, krewnymi oraz wirtualnymi znajomymi; dzięki Internetowi uzyskali możliwość dostępu w dowolnym czasie do międzynarodowych opracowań zagadnień naukowych, politycznych, ekologicznych czy relacji z wydarzeń. Ludziom na całym świecie zostały udostępnione wirtualne muzea, galerie, wystawy, biblioteki i archiwa. Jakościowo poszerzyły się możliwości gromadzenia i wykorzystywania informacji przez człowieka, zwiększyła się skala dostępnych dla niego zasobów informacyjnych, otworzyły się nowe możliwości wymiany wiedzy. Nowoczesne mass media za- 
pewniły sposobność połączenia wszystkich sfer życia społecznego w jednolitą i dostępną człowiekowi przestrzeń informacyjną, która ułatwia nawiązywanie relacji między ludźmi, narodami, państwami, a także tworzy możliwości interaktywnego dialogu między każdym podmiotem na ziemskim globie.

Pojawienie się nowych rodzajów mass mediów mogłoby zagwarantować powstanie nowego typu jedności społeczności światowej: jednolitej światowej cywilizacji, dla której charakterystyczne byłoby uświadomienie sobie przez wszystkich mieszkańców globu ich własnej wspólnoty, współzależności, współodpowiedzialności za los całej ludzkości. Jednak możliwości, jakie ludzie uzyskali dzięki nowoczesnym mass mediom, nie zmniejszyły panującego na świecie odosobnienia, społecznego odizolowania, indywidualizmu ani wyobcowania poszczególnych ludzi. Podstawową tendencją nowoczesnego społeczno-politycznego rozwoju stała się polaryzacja struktury społecznej ludzkości, którą często opisuje się za pomocą terminów: izolowany świat „złotego miliarda” - „outsiderzy”, „Północ - Południe”, „centrum - peryferie". Zasoby informacyjne, analogicznie jak zasoby finansowo-ekonomiczne, surowcowe, naukowo-techniczne albo militarno-polityczne pozostają skoncentrowane w krajach Zachodu, w krajach „złotego miliarda”. Sprzyjająca im ideologia indywidualizmu rozpowszechnia się za pomocą nowoczesnych mass mediów, wpływając na świadomość milionów ludzi.

Nowoczesne mass media wniosły istotne zmiany w życie ekonomiczne i społeczno-polityczne. Rewolucja informacyjna ostatnich dziesięcioleci $\mathrm{XX}$ wieku przyniosła nie tylko system sieci informacyjnych zdolnych do przekazywania na dowolną odległość niezbędnych informacji, ale także zaowocowała powstaniem technologii umożliwiających kształtowanie społecznej i indywidualnej świadomości, formowanie preferencji, stylów, stanowisk, nastrojów politycznych. Następstwem rewolucji informacyjnej stała się indywidualizacja społeczeństwa, która ma zarówno obiektywne, jak i subiektywne przyczyny. Nowe technologie dostarczyły nie tylko możliwości poszukiwania oraz przekazywania informacji, ale także urzeczywistnienia permanentnej, w dodatku prowadzonej na dużą skalę kontroli świadomości zarówno indywidualnej, jak i społecznej, a w konsekwencji także sposobność dokonywania zmian tej świadomości. Systemy informacyjne dysponują taką

${ }^{1}$ Termin użyty przez Aleksandra Panarina (zm. w 2003 r.) na określenie ekonomiczno-politycznej elity skupiającej w swoich rękach władzę i bogactwo całego świata, a jednocześnie stojącej w opozycji wobec zmarginalizowanych pozostałych pięciu miliardów mieszkańców Ziemi [przyp. tłum.]. 
siłą wywierania wpływów, że roztaczają przed człowiekiem szczególną rzeczywistość - rzeczywistość wirtualną. Ludźmi, którzy żyją w tej realności, łatwiej kierować, łatwiej ich zachęcać do oddawania głosów na określonych polityków albo określone formacje polityczne, łatwiej zmanipulować ich do kupowania reklamowanych towarów lub usług.

Jednymi z pierwszych, którzy postawili pytanie o konieczność uświadomienia sobie procesu powstawania nowego społeczeństwa oraz wpływu mass mediów na jego rozwój, byli przedstawiciele szkoły frankfurckiej - grupy uczonych, skupiających się od 1930 roku wokół Instytutu Badań Społecznych w Frankfurcie nad Menem i istniejącej do początku lat siedemdziesiątych XX wieku. Przedstawiciele szkoły frankfurckiej jako pierwsi w filozofii zachodniej podjęli się analizy mass mediów jako narzędzi manipulacji oraz nacisku wywieranego na osobowość. Swoje zadanie dostrzegali w formowaniu myślenia krytycznego, jako jedynej możliwej współcześnie wyalienowanej formy działalności. Dzięki krytyce fetyszyzmu towarowego, ideologii konsumpcyjnej, dzięki ujawnieniu manipulacji ze strony władzy oraz dzięki analizom sposobów oddziaływania, opracowywali strategię postępowania zapewniającego możliwość uchylenia się przed podporządkowaniem się systemowi i totalną kontrolą ze strony władzy.

Przedstawiciele szkoły frankfurckiej (M. Horkheimer, T. Adorno, E. Fromm, G. Marcuse, J. Habermas i inni) mass media rozpatrywali jak narzędzie rozpowszechnienia idei oraz światopoglądu preferowanych przez klasę panującą oraz jako środek uzyskania dodatkowego zysku ze sprzedaży konsumentom wytworów masowej produkcji. Twierdzili, że procesy społeczne zależą od norm kulturalnych, które za pomocą nowoczesnych środków technicznych wnikają $\mathrm{w}$ świadomość społeczną. W swoich pracach badali wpływ środków masowego przekazu na procesy historyczne (M. Horkheimera, T. Adorno), na formowanie się fałszywego obrazu świata i konsumpcyjnego stosunku do życia (E. Fromm), na powstawanie „człowieka jednomiarowego" (H. Marcuse), na problem jawności i rozumu komunikacyjnego, tworzenia się „nowej nieprzejrzystości” (J. Habermas).

Przemilczanie przez środki masowego przekazu alternatywnych punktów widzenia staje się narzędziem ideologizacji społeczeństwa, które budzi zainteresowanie w kręgach władzy, podkopuje możliwości kształtowania się aktywnej i zorganizowanej opozycji. Ci, którzy dysponują mass mediami oraz podejmują decyzje, tworzą wiedzę o społeczeństwie i dla społeczeństwa. Na skutek tych działań zmniejsza się liczba niezależnych środków masowego przekazu, nasila się koncentracja mass mediów na większych rynkach. 
W warunkach, w których współcześnie spotykamy sięz problemami atomizacji społeczeństwa, w sytuacji słabnących kontaktów interpersonalnych, wobec utraty poczucia społecznej i moralnej solidarności, idee jednego z przedstawicieli szkoły frankfurckiej, Herberta Marcuse (1898-1979) o roli mass mediów w formowaniu się „człowieka jednomiarowego” ponownie stają się aktualne w społecznym dyskursie. Utworzone przez niego terminy: „człowiek jednomiarowy”, „społeczeństwo jednomiarowe”, „myślenie i działanie jednomiarowe”, „potrzeby represyjne”, „cywilizacja represyjna” znajdują zastosowanie w opisie nowoczesnego społeczeństwa konsumpcyjnego. W swojej filozofii $\mathrm{H}$. Marcuse próbował łączyć zapożyczenia czerpane od K. Marksa, elementy krytycznego podejścia do społeczeństwa mieszczańskiego, z ideami heglowskiej dialektyki i psychoanalizy Z. Freuda.

H. Marcuse, przedstawiciel teorii krytycznej, który w pracy Eros $i$ cywilizacja (1955) charakteryzowł nowoczesne społeczeństwo jako cywilizację represyjnąㄹ z z czasem, w pracy Człowiek jednomiarowy (1964), charakterystykę społeczeństwa uzupełnił o pojęcia ciwilizacji technologicznej, przemysłowej, jednowymiarowej ${ }^{3}$. Zawartymi $w$ tych pracach analizami H. Marcuse położył podwaliny pod ideologię „,nowej lewicy” oraz teoretyczny fundament studenckiego ruchu lat sześćdziesiątych XX wieku, kiedy to pod wpływem jego idei studenci podnieśli protest przeciwko skrajnie stechnicyzowanemu i zbiurokratyzowanemu konsumpcyjnemu społeczeństwu, przeciw „represyjnej tolerancji”. Teoria krytyczna H. Marcusego, nastawiona na troskę o szczęście człowieka, rozwój ludzkich możliwości, wolności i praw jednostki, żądanie uwolnienia ludzkich relacji poprzez zniesienie dawnych materialnych warunków życia.

Po upływie pół wieku od napisania tych prac, ponownie stały się one przedmiotem zainteresowania. Jego koncepcja „społeczeństwa jednowymiarowego" pozostaje aktualna także w warunkach współczesnego społeczeństwa, z jego technikami manipulowania ludzką świadomością. Historia nigdy dotąd nie znała tak totalnego, przenikającego wszystko panowania i kontroli mass mediów nad społeczeństwem i indywiduum, jakie występuje w naszych czasach. W wyniku technologicznego postępu obecnie we wszystkich sferach ludzkiego życia istnieje totalna kontrola oraz możliwość wywierania wpływu.

\footnotetext{
${ }^{2}$ Wyd. pol. H. Marcuse, Eros i cywilizacja, tłum. H. Jankowska, A. Pawelski, Warszawa 1998 [przyp. tłum.].

${ }^{3}$ Wyd. pol. H. Marcuse, Człowiek jednowymiarowy: badania nad ideologia rozwiniętego społeczeństwa przemysłowego, wstęp W. Gromczyński, tłum. S. Konopacki, Z. Koenig i in., Warszawa 1991 [w dalszej części cytuję według wydania polskiego - przyp. tłum.].
} 
Za sprawą nowoczesnych mass mediów ludzie tracą zdolność krytycznego myślenia, zanika u nich oryginalność, przekształcają się w konformistów. Władza natomiast zawsze próbowała uzyskać kontrolę nad mass mediami. Dlatego działalność zinstytucjonalizowanych mediów skierowana jest raczej na zachowanie istniejącego porządku, aniżeli na jego zmianę.

Marcuse w pracy Człowiek jednowymiarowy społeczeństwo stworzone przez przemysł kultury określił jako jednowymiarowe, totalitarne, represyjne (pojęcia „represja” używa on dla określenia procesów zahamowania, przymusu i stłumienia, zarówno w odniesieniu do osobowości, jak i do społeczeństwa). Społeczeństwo, ustanowiwszy władzę nad człowiekiem, usprawiedliwia swoje działania osiągniętym dobrobytem. H. Marcuse zwraca uwagę na pośredniczącą rolę mass mediów w tym procesie:

Ten rodzaj dobrego samopoczucia, produktywna nadbudowa znajdująca się nad nieszczęśliwą bazą społeczną, przenika „środki” przekazu, które pośredniczą między władcami i ich podwładnymi. Jego agenci reklamowi nadają kształt uniwersum komunikacji, w którym wyraża siebie jednowymiarowe zachowanie. Jego język świadczy o identyfikacji i unifikacji, o systematycznym popieraniu pozytywnego myślenia i działania, o zgodnym ataku na transcendujące pojęcia krytyczne ${ }^{4}$.

Według H. Marcusego u podstaw nowoczesnej, rozwiniętej cywilizacji przemysłowej leży określony projekt historyczny - projekt technologicznej racjonalności, którą traktuje się tu jako siłę napędową społecznego rozwoju, jako wcielenie „technicznego uniwiersum”, dające możliwość urzeczywistnienia totalnej kontroli i zarządzania. Naukową racjonalność rozumie on zaś jako określoną technologię, a technologię - „jako formy społecznej kontroli i panowania"s. Jednakże dążenie człowieka co panowania nad przyrodą w celu osiągnięcia satysfakcji wynikającej ze spełnienia własnych potrzeb okazuje się brzemienne w katastrofalne skutki zarówno dla przyrody, jak i dla samego człowieka. Niezdolność człowieka do rezygnacji z dóbr cywilizacyjnych, z satysfakcji realizowania fałszywych potrzeb, odsuwa szansę jakiegokolwiek alternatywnego rozwoju społecznego. Sam sposób zorganizowania nowoczesnego społeczeństwa czyni je społeczeństwem totalitarnym, jak uważa H. Marcuse, podkreślając, że określenie „totalitarne” oznacza „nie tylko terrorystyczne, polityczne uporządkowanie społeczeń-

4 Tamże, s. 115.

${ }^{5}$ Tamże, s. 199. 
stwa, lecz także jego nie-terrorystyczne, ekonomiczno-techniczne uporządkowanie, które działa poprzez manipulowanie potrzebami przez właścicieli kapitału"'.

Żeby uniknąć protestów społeczeństwa, władza, za pomocą mass mediów, zaspokaja jego materialne i intelektualne potrzeby. Potęga władzy i biznesu nie daje jednak możliwości realizowania ekonomicznej wolności, którą H. Marcuse rozumie jako wolność „od bycia kontrolowanym przez ekonomiczne siły i stosunki; wolność od codziennej walki o byt, od zdobywania środków do życia”, natomiast wolność polityczną rozumie, jako „wyzwolenie jednostek od polityki, nad którą nie mają żadnej skutecznej kontroli”. Szczególną aktualność uzyskują współcześnie, w warunkach indywidualizacji społeczeństwa, słowa H. Marcusego, że „wolność intelektualna oznaczałaby odrodzenie się myśli indywidualnej, pochłoniętej dzisiaj przez masową komunikację i indoktrynację, oraz zniesienie „opinii publicznej” wraz z jej twórcami"7.

Technika manipulowania świadomością kształtuje potrzeby człowieka, motywy jego postępowania, jego czyny i działania. Wszystko to wzmacnia przemianę świadomości, formuje ,jednowymiarowość”, prowadzi do zagubienia krytycznego, zdystansowanego stosunku do rzeczywistości. „Jednowymiarowość" jawi się jako społeczny fenomen współczesności, która niweluje, usuwa konflikty i sprzeczności. W społeczeństwie ludzi „jednowymiarowych” nie ma mowy o protestach. To społeczeństwo bez opozycji, w której krytyka pozostaje sparaliżowana wszechobecną kontrolą, gdzie „panowanie - pod maską obfitości i swobody - rozciąga się na wszystkie sfery prywatnego i publicznego istnienia, podporządkowuje sobie wszelką autentyczną opozycję, wchłania wszystkie alternatywy. Technologiczna racjonalność odsłania swój charakter polityczny w miarę, jak staje się wielkim środkiem lepszego panowania, tworzącym prawdziwie totalitarne uniwersum, w którym społeczeństwo i przyroda, umysł i ciało utrzymywane są w stanie ciągłej mobilizacji dla obrony tego uniwersum".

H. Marcuse wskazuje na paradoks społeczeństwa, które osiągnęło techniczne możliwości zrealizowania zarówno dobrobytu, jak i najwyższych wartości ludzkich, ale zamiast tego używa swojej potęgi do stłumienia krytyki i opozycji. W artykule Bemerkungen zu einer Neubestimmung der Kultur (1965)

\footnotetext{
${ }^{6}$ Tamże, s. 19.

7 Tamże, s. 21.

${ }^{8}$ Tamże, s. 37.
} 
H. Marcuse dokonuje rozróżnienia pomiędzy „kulturą” jako wartościami, ku którym zwraca się społeczeństwo oraz „cywilizacją” jako materialnym fundamentem życia społeczeństwa i wskazuje, że kultura znajduje się $\mathrm{w}$ permanentnej sprzeczności $\mathrm{z}$ cywilizacją. Tymczasem $\mathrm{w}$ rozwiniętym społeczeństwie przemysłowym kulturę mierzy się standardami praktycznego sukcesu. Nowoczesna kultura i nauka stają się instrumentami panowania, zarówno ze strony państwa, jak i korporacji, które używają nowoczesnych osiągnięć do realizacji własnych celów. H. Marcuse wyraża zaniepokojenie $\mathrm{z}$ tego powodu, że pojawiające się nowe techniczne możliwości w dziedzinie mass mediów mogą zostać użyte do kolejnego wystąpienia przeciwko prawom i wolnościom człowieka. Postawiony przez niego problem: „Podbój kosmosu może przyśpieszyć i rozwinąć środki komunikacji i informacji, jednakże pozostaje kwestią, czy aby nie są one już nadmiernie szybkie i rozwinięte, by komunikować się za ich pomocą" "współcześnie zyskuje szczególną aktualność.

Każdy $\mathrm{z}$ nas często spotyka się z jakimiś metodami manipulowania świadomością, którą posługują się mass media. Dotyczy to takiego konstruowania informacji, podczas którego niektóre frazy wyrywa się $\mathrm{z}$ kontekstu i celowo zmienia się ich sens, powstają w ten sposób nowe informacje utworzone $\mathrm{z}$ urywków wypowiedzi albo zapisu telewizyjnego. Informacje te łączy się w taki sposób, ażeby człowiekowi łatwo było je przyswajać. Często podczas takiego zabiegu informacja podlega znormalizowaniu, podpada pod określony stereotyp. Sprzyja to odbieraniu wiadomości bez intelektualnego wysiłku, bez krytycznej analizy. Mass media uczą człowieka myśleć stereotypami. Powtarzanie informacji, która jest korzystna z perspektywy władzy, kształtowanie strumienia informacji w taki sposób, ażeby zaaranżować pozór określonej rzeczywistości, staje się ważnym czynnikiem $\mathrm{w}$ walce przeciwko opozycji.

"Człowiekiem jednomiarowym” H. Marcuse nazywa człowieka żyjącego w społeczeństwie o jednym wymiarze, kierowanym filozofią technologicznej racjonalności. W społeczeństwie technologicznym aparat państwowy dąży do władzy absolutnej, wyznaczając nie tylko zatrudnienie oraz społeczne formy zachowania, ale także indywidualne potrzeby. Technologiczne uniwiersum dąży do tego, by przekształcić się w uniwersum polityczne. „W tym uniwersum technologia dostarcza również znakomitej racjonalności dla nie-wolności człowieka i wykazuje „techniczną” niemożliwość istnienia autonomicz-

${ }^{9}$ H. Marcuse, Bemerkungen zu einer Neubestimmung der Kultur, [w:] tenże, Kultur und Gesellschaft, Bd. 2, Frankfurt am Main 1968, s. 170. 
nego, określania swego własnego życia. A to dlatego, że ta nie-wolność jawi się nie jako irracjonalna, ani też polityczna, lecz raczej jako uległość wobec technicznego aparatu, który powiększa komfort życia i podnosi wydajność pracy. W ten sposób technologiczna racjonalność ochrania raczej niż unieważnia legalność panowania, a instrumentalny horyzont rozumu otwiera się na racjonalnie totalitarne społeczeństwo" ${ }^{\prime 10}$.

Rozwiniętą cywilizację przemysłową $H$. Marcuse charakteryzuje używając słów: „Wygodna, uładzona, rozsądna, demokratyczna nie-wolność [, która - T. K.] dominuje w rozwiniętej cywilizacji przemysłowej" ${ }^{11}$. Jest to społeczeństwo zdolne powstrzymywać każdą jakościową zmianę w wymaganych czasowych ramach, a jego wyrafinowane techniki kontroli zapewniają człowiekowi iluzję wolności. W ten sposób społeczeństwo, unieważniając krytyczne myślenie, unicestwia samą możliwość zmiany. H. Marcuse podstawową zdolność samoregulacji nowoczesnej przemysłowej cywilizacji nazywa represją, tzn. stłumieniem popędów i potrzeb większości, a także tworzeniem standardowych, fałszywych potrzeb, wiążących ściśle indywiduum z nowoczesnym społeczeństwem (potrzeb represyjnych). Fałszywymi potrzebami nazywa on te potrzeby, „które są narzucone jednostce w procesie jej represjonowania, przez partykularne interesy społeczne: które utrwalają znój, agresywność, cierpienie i niesprawiedliwość. Ich zaspokojenie mogłoby być czymś najbardziej przyjemnym dla jednostki, jednak takie szczęście nie jest stanem, który powinien być utrzymywany i chroniony, jeśli służy on zahamowaniu rozwoju zdolności (jej własnej lub innych ludzi) do rozpoznania choroby całości i uchwycenia szans wyleczenia. Rezultatem jest wtedy euforia w nieszczęściu. Większość przeważających potrzeb wypoczynku, zabawy, zachowywania się i konsumowania zgodnie z tym, co zaleca reklama, kochania i nienawidzenia tego, co kochają i nienawidzą inni, należy do tej samej kategorii potrzeb fałszywych"12. Indywiduum traci ontologiczne i moralne podstawy, na których mogłoby rozwinąć swoją autonomię, a tym bardziej zdolność przeciwstawiania się całemu społeczeństwu. Kształtuje się $\mathrm{w}$ ten sposób model jednowymiarowego myślenia oraz działania, zarówno na poziomie indywiduum, jak i na poziomie procesów społecznych. W warunkach, w których świadomość człowieka stale poddawana jest naciskowi środków masowego przekazu, gdy nieustannie jest wypełniana najroz-

\footnotetext{
${ }^{10}$ H. Marcuse, Człowiek jednowymiarowy, s. 200.

11 Tamże, s. 17.

12 Tamże, s. 21-22.
} 
maitszymi nowymi i sensacyjnymi informacjami, pojawia się stan napięcia nerwowego, poczucie nieprzerwanego kryzysu. W takich warunkach podnosi się u ludzi drażliwość, a jednocześnie zmniejsza się zdolność do krytycznego myślenia. O tego rodzaju manipulowaniu świadomością, w którym nieprzerwana dynamika rozwoju technicznego zostaje nasycona polityczną treścią H. Marcuse pisał w następujących słowach: „W tym uniwersum technologia dostarcza również znakomitej racjonalności dla nie-wolności człowieka i wykazuje „techniczną” niemożliwość istnienia autonomicznego, określania swego własnego życia. A to dlatego, że ta nie-wolność jawi się nie jako irracjonalna, ani też polityczna, lecz raczej jako uległość wobec technicznego aparatu, który powiększa komfort życia i podnosi wydajność pracy"13. Za życie w społeczeństwie obfitości, za komfort, biznes i zapewnienie pracy człowiek odpłaca się ciężką pracą i wzrostem niezadowolenia.

Dla człowieka nowoczesnego czymś naturalnym stała się przewaga fałszywych potrzeb, które narzucają się nam za sprawą reklamy, mody, określonych stereotypów i są wciąż narzucane przez mass media. H. Marcuse wzywa do krytycznego stosunku wobec potrzeb, które podsuwane są nam przez środki masowego przekazu. „Jedynymi potrzebami, które na osiągniętym poziomie kultury bezwarunkowo domagają się zaspokojenia, są potrzeby życiowe - pożywienie, ubranie, mieszkanie" ${ }^{\prime 4}$. Pozostałe potrzeby każdy świadomie powinien poddawać weryfikacji. Prawo ostatecznej decyzji przynależy do samego indywiduum, ale tylko wtedy, jeśli jest ono wolne na tyle, by udzielić własnej odpowiedzi i realnie dokonać rozróżnienia pomiędzy mass mediami jako środkami dostarczającymi informacji i rozrywki oraz mass mediami jako czynnikami służącymi do manipulowania i oddziaływania na świadomość; by samodzielnie rozpoznać formy społecznej kontroli technologicznej. Narzucanie fałszywych potrzeb dokonuje się za pomocą technologii informacyjnych, poprzez wypełnianie ich określoną treścią, a także dzięki samej naturze ich funkcjonowania - technicznej powtarzalności, wszechobecności. H. Marcuse zauważa, że technika, technologie informacyjne same $\mathrm{w}$ sobie pozostają neutralne, a jedynie ich związek $\mathrm{z}$ aparatem władzy ukierunkowuje je w określony sposób. Ujawnia on jedynie polityczne aspekty panującej technologicznej racjonalności:

\footnotetext{
13 Tamże, s. 200.

14 Tamże, s. 22.
} 
Aparat produkcyjny oraz dobra i usługi przezeń wytwarzane „sprzedają”, czy też narzucają, system społeczny jako całość. Środki masowego transportu i komunikacji, wyposażenie mieszkań, żywność i ubranie, niepowstrzymany zalew produkcji przemysłu rozrywkowego i informacyjnego niosą ze sobą wyznaczone postawy i zwyczaje, określone intelektualne i emocjonalne reakcje, które więcej lub mniej przyjemnie wiążą konsumentów z producentami, a przez nich $\mathrm{z}$ całością. Wyroby indoktrynują, manipulują; wspierają fałszywą świadomość, która nie zauważa własnego fałszu ${ }^{15}$.

W swoich pracach H. Marcuse podejmuje problem psychologii zniewolonego przez mass media współczesnego człowieka. W wyniku ich oddziaływania kształtuje się bowiem w człowieku stereotypowość i jednowymiarowość sposobu myślenia. H. Marcuse uważa, że takiemu wpływowi ulega całe środowisko przedmiotowe i informacyjne, doprowadzając do powstania fenomenu „myślenia jednowymiarowego". W społeczeństwie jednowymiarowym priorytetem staje się doskonalenie systemu konsumpcji, a to, jak określa H. Marcuse, stwarza „paraliż krytycyzmu” oraz „społeczeństwo pozbawione opozycji”. Pojawia się typ jednowymiarowego myślenia i zachowania, w którym idee, dążenia oraz cele wykraczające w swojej treści poza ramy ustalonego świata opinii i sposobów postępowania, zostają albo odrzucone, albo wchłonięte do języka, jakim posługuje się ten świat. Człowiek traci charakterystyczną dla niego zdolność krytycznego myślenia, która przybiera postać odpowiadającą dążeniom jego konsumpcyjnej świadomości.

Pojawienie się nowych rodzajów mass mediów wpływa na zmianę ogólnej psychologii społeczeństwa, ponieważ nowe techniki komunikacyjne rozwijają jedne, a jednocześnie hamują inne cechy społecznego charakteru. Nowe rodzaje technik komunikacyjnych, przede wszystkim pojawienie się Internetu, a także umasowienie produkcji, które stało się skutkiem wynalezienia nowych technologii, doprowadziły do radykalizacji procesów zindywidualizowania społeczeństwa. Masowa produkcja form kultury sprzyja zrywaniu międzyosobowych więzi, jest katalizatorem jednowymiarowości społeczeństwa. Normalizujący wpływ techniki i technologii na jednostkę oraz zanik tradycyjnych form relacji między ludźmi przekształcają jednostkę w zatomizowanego człowieka, który utracił więź z przyjaciółmi, rodziną, sąsiadami oraz z innymi grupami społecznymi. Dla człowieka-atomu najwyższą wartością staje się poczucie własnej wyjątkowości, dążenie do samopotwierdzenia, niezależności od innych jednostek, połączone z dążeniem do ekonomiczne-

15 Tamże, s. 30. 
go sukcesu i dobrobytu. Taki typ człowieka gotowy jest poprzeć każdą ideę, każdy system wartości, w tym nawet amoralny, jeśli tylko sprzyjać to będzie zachowaniu osiągniętego poziomu potrzeb, i jeśli postawa taka zagwarantuje mu stabilność jego bytu. W tych warunkach refleksje H. Marcusego zyskują szczególną aktualność. Nowe rodzaje mass mediów otworzyły nieosiągalne dotąd możliwości wpływania na świadomość zarówno człowieka, jak i społeczeństwa. W tej sytuacji jedynie wolna, wielowymiarowa osobowość może zmienić porządek społeczny, stworzony przez władzę człowieka nad przyrodą oraz człowieka nad drugim człowiekiem. Tylko zmiana ludzkiej świadomości może uchronić ludzką istotę przed katastrofą.

Przełożył Tomasz Kupś

\title{
Bibliografia
}

G. Markuze, Ėros i civilizaciâ. Odnomernyj čelovek: Issledovanie ideologiirazvitogo industrial'nogo obŝestva, Moskva 2003.

G. Markuze, Zamečaniâ k utočneniû opredeleniâ kul'tury, w: tenże, Kritičeskaâ teoriâ obŝestva: Izbrannye raboty po filosofiii social'noj kritike, Moskva 2011.

H. Marcuse, Eros i cywilizacja, tłum. Hanna Jankowska, Arnold Pawelski, Warszawa 1998.

H. Marcuse, Człowiek jednowymiarowy: badania nad ideologia rozwiniętego społeczeństwa przemysłowego, wstęp Wiesław Gromczyński, tłum. Stanisław Konopacki, Zofia Koenig i in., Warszawa 1991.

H. Marcuse, Kultur und Gesellschaft, Bd. 2, Frankfurt am Main 1968.

\author{
Abstract \\ Reception Areas of Mass Media in the Culture \\ of One-dimensional Society after Herbert Marcuse
}

In the article the author researches the problem of modern mass-media influence upon the ideologization of society and the appearance of "one-dimensional" man on the basis of $\mathrm{H}$. Marcuse's ideas. According to $\mathrm{H}$. Marcuse's statement that modern culture created by means of mass-media deprives a person of any real alternatives 
to the existing and thinking the author rises the problem of manipulation of mass consciousness in modern conditions.

Key words: H. Marcuse, „one-dimensional” society, „one-dimensional” man, mass-media, manipulation of consciousness 